\title{
Received $\quad 06.08 .2018$ \\ Effect of two management techniques applied to the reduction of Juncus maritimus (Lam.) abundance in a selected temporary wetland
}

\author{
Nargis SAHIB ${ }^{\text {ABCDEF } \bowtie}$
}

orcid/org. 0000-0002-9676-7585; Mohamed I University, Faculty of Science, Department of Biology, Laboratory of Biology of Plants and Microorganisms (LBPM), Oujda, Morocco; e-mail: sahib.nargis@gmail.com

\begin{abstract}
For citation: Sahib N. 2019. Effect of two management techniques applied to the reduction of Juncus maritimus (Lam.) abundance in a selected temporary wetland. Journal of Water and Land Development. No. 41 (IV-VI) p. 120-132. DOI: 10.2478/jwld2019-0035
\end{abstract}

\begin{abstract}
Moderate management of temporary wetlands is one of the most proper methods for their restoration and conservation. The cessation of use may lead to high biomass domination by macrophytes as Juncus maritimus (Lam.) that changes plant community structure, threatens species biodiversity, and becomes a danger for their conservation. The experiment was carried out in Sidi Boughaba coastal reserve in Morocco. Two management techniques of wetlands were tested, cutting and uprooting of the rush. Four experimental plots $(4.2 \times 2.9 \mathrm{~m})$ within the rush belt were set up, with intact plots as a control. Vegetation structure and water levels were monitored on 96 quadrats over two years. The six visits dates, three visits per year (February, April, June), were monitored over two years. The abundance and richness of species were studied, simultaneously with the density of the seed stock in each plot. Results showed that both techniques allowed the opening of the habitat with a significant increase of richness and abundance of species, particularly the restoration of characteristic species of the temporary wetland from the seed bank. The cut technique seems to have less of an effect on the seed stock, total seeds median value was 6.5 in cut plots versus 5 in uprooting plots, being regularly applied given the rapid encroachment of the rush.
\end{abstract}

Key words: conservation of temporary wetlands, experimental approach, Juncus maritimus (Lam.), rush, seed bank, techniques of management

\section{INTRODUCTION}

Among the Mediterranean region, temporary wetlands are habitats of high biodiversity interest; particularly because of the rare and endangered species they harbour [BIGGS et al. 2005; ERWIN 2009; MEDAIL et al. 1998; OERTLI et al. 2008; WILLIAMS et al. 2004]. In these habitats species can use different strategies to establish [SAHIB 2018]. In Europe, they are recognized as priority areas regarding conservation (Natura Code 3170 [Council Directive 92/43/CCE]), and protection [MIODUSZEWSKI, OKRUSZKO 2012]. The species of plants present in temporary wetlands are dominated by annual species, adapted to the alternation of dry and wet phases, and the huge interannual variation in high and duration of flooding [DE BÉLAIR 2005].

Recently, temporary wetlands have gained significant prominence but yet remain overlooked with inadequate management [SNODGRASS et al. 2000]. Traditional land use practices by local people have always existed with biodiversity conservation, and have been of great benefit for habitats [BEJA, ALCAZAR 2003; GRILlAS, ROCHÉ 1997] by supporting the conservation of threatened species after the habitat opening due to high biomass harvest, that supports rural people's small economic activities [GóMEZ-BAggethun et al. 2010]. Since halophytes (e.g. Phragmites australis (Cav.) Trin. ex Steud., Juncus maritimus (Lam.)) are harvested for traditional handicraft and (e.g. Papus spp.; Typha spp.) are used as a source of biomass energy [JONES et al. 2016; LISHAWA et al. 2015].

The abandonment of moderate traditional land uses have led to a high biomass domination, which consequently changed the plant community structure in many habitats [BIGNAL, MCCRACKEN 1996; KedDy 2010; MACDONALD et al. 2000], as the case in temporary wetlands it leads to 
a habitat deterioration by a strong dynamics of macrophytes and woody species [GRILLAS, TAN HAM 1998]. These traditional practices appear to play an important role in conserving the biodiversity [O'ROURKE 2006; PLIENINGER et al. 2006], and were reported as management methods of macrophytes and perennials.

Macrophytes succession is usually accompanied by a change in the physical characteristics of the environment [BLOSSFELD et al. 2011; BREZINOVÁ, VYMAZAL 2014]. Litter accumulation, and enrichment of the soil with organic matter has an effect on the vegetation dynamics and species recruitment, resulting in the modification of the biological richness. The effect is more pronounced on rare and characteristic species [HOULAHAN, FINDLAY 2004] that life traits (e.g. small size, weak competitiveness) are a disadvantage in highly colonised habitats.

As in temporary wetlands, the conservation of characteristic species involves the opening up of the habitat with the appropriate management of competitive plants [ERVIN, WETZEL 2002]. Cutting and burning have been experimentally tested to restore the biodiversity and richness of wet habitats [ZEDLER 2000], or by a combination of multiple management strategies [MILLER 2016]. The choice of the efficient technique depends strongly on, the physical and the biological properties of the habitat as well as financial cost [MILLER, HOBBS 2007].

In the north-west of Morocco, the temporary wetland of Sidi Boughaba's coastal reserve has always been grazed by cattle, and the rushes Juncus maritimus (Lam.) were harvested by the local people for traditional handicrafts. Since the 1980s and after the enclosing of the reserve [ATBIB 1979-1980; RAMDANI et al. 2001], these traditional activities have been abandoned, and a strong dynamic of rushes has been observed. The reserve is undergoing rushes domination (Fig. 1).

The main assumptions of this work are:

- cutting and uprooting increase the abundance and richness of species, by reducing competition and allowing the establishment of seeds from the undisturbed vertical stratification of seeds stock; the efficient method is cutting, and the expected increase is greater for annual species more than perennials, and also greater for characteristic species of a temporary wetland than for terrestrials;

- uprooting the rushes reduces the density and the richness of seed stock, because of the disturbance of the soil's vertical stratification by roots removal;

- interannual dynamic of vegetation is greater when uprooting, more than when cutting with a leading role of hydrology.

The main hypothesis for this work is that the spreading and condensation of rushes Juncus maritimus (Lam.) leads to a regression of abundance and richness of herbaceous species particularly the characteristic species of temporary wetlands. Restoration treatments are necessary to reduce the high biomass of macrophytes and consequently allow characteristic species to become established from seed stocks. Furthermore, to suggest adequate management methods for a general model which could be related to temporary wetlands, the aim of the current study is to con-

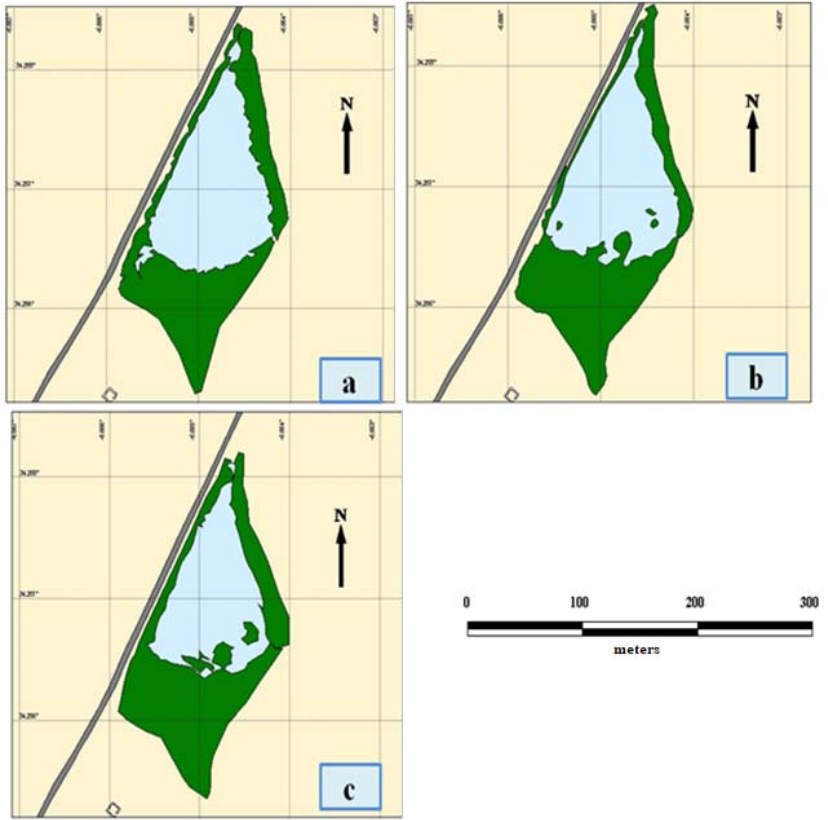

Fig. 1. Dynamic of the rush Juncus maritimus (green belt) around the studied temporary wetland; a) twenty years before the enclosing, b) twenty years after the enclosing, c) thirty years after the enclosing; source: own elaboration based on the aerial photographs of the Mapping Service and the Google Earth environment for visualizing images software was used for image analysis

duct a test in a (cutting vs. uprooting) experiment, to explore the possibility of restoring characteristic species of temporary wetlands being colonised by rushes Juncus maritimus (Lam.). For this reason, the study combined a test of (cutting vs. uprooting) clearance in the field with seed stock germination.

\section{MATERIALS AND METHODS}

\section{STUDY AREA}

Experimental management of rushes Juncus maritimus (Lam.) (cutting vs. uprooting) for the restoration of the biodiversity, particularly characteristic species of one selected temporary wetlands were set up simultaneously with a seed bank study. The experiment was carried out in the temporary wetland located at the upper northern side of the wet complex of Sidi Boughaba (34ำ $12^{\prime} \mathrm{N} ; 6^{\circ} 42^{\prime}$ E), located in the North-West coast of Morocco (Fig. 2) by the estuary of the Sebou River. The wet complex puts together:

- a permanent shallow lake $(<3 \mathrm{~m}$ deep) extending to a $\sim 6 \mathrm{~km}$ long depression, that separates on the east side coastal mobile dunes (20-30 m high) and fossilised dunes ( $\sim 50 \mathrm{~m}$ high);

- a small seasonal wetland, adjacent to the lake, that the surface water flows down into the lake during heavy floods;

- a temporary wetland, that fills with water during the rainy season and dries out during the summer.

The 650 ha depression, including the temporary wetland, the seasonal wetland and the permanent lake, was established as a National Nature Reserve in 1975 and des- 


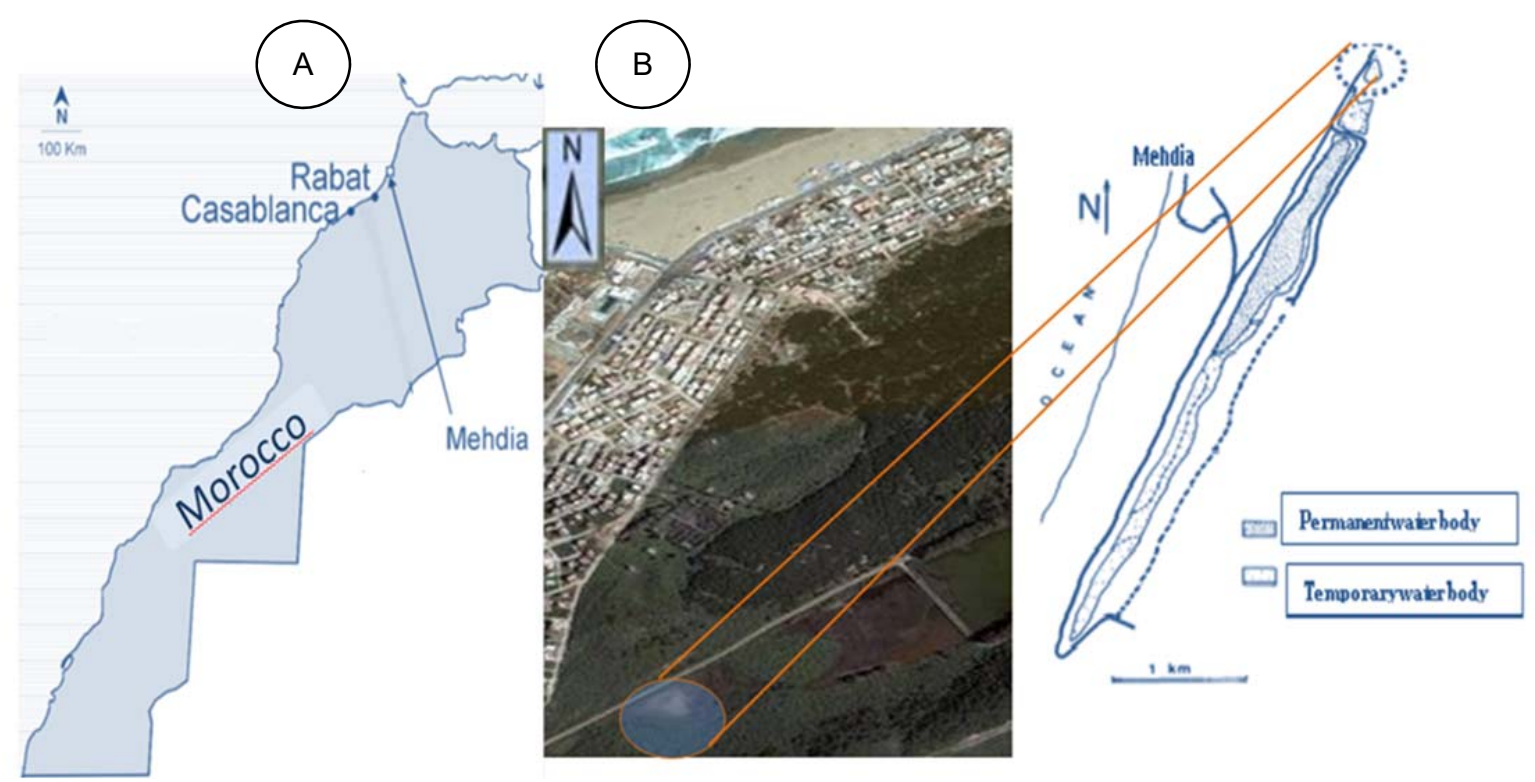

Fig. 2. Map of the wet complex of the reserve of Sidi Boughaba located by the estuary of the Sebou River near the Mehdia (North-West Morocco); dotted circle = the temporary wetland of the reserve (the study site); source: a) ATBIB 1983, B) aerial photography of the study site by Google Earth

ignated as a site of international importance by the Ramsar convention in 1980.

Sidi Boughaba reserve is subject to a Mediterranean climate with Atlantic influence ensuring yearly rainfall of between $500-600 \mathrm{~mm}$. The Mediterranean climate is characterized by dry summers, mild winters and a very variable amount of rainfall from year to year. The Mediterranean climate is influenced by the Atlantic Ocean that produces a sub-humid Mediterranean climate with mild, moist winters from October until March/April, and hot, dry summers from May until September. The annual average temperature is of $18.4^{\circ} \mathrm{C}$. The average of the annual precipitation reaches $570 \mathrm{~mm}$ [ZAIDI et al. 2016].

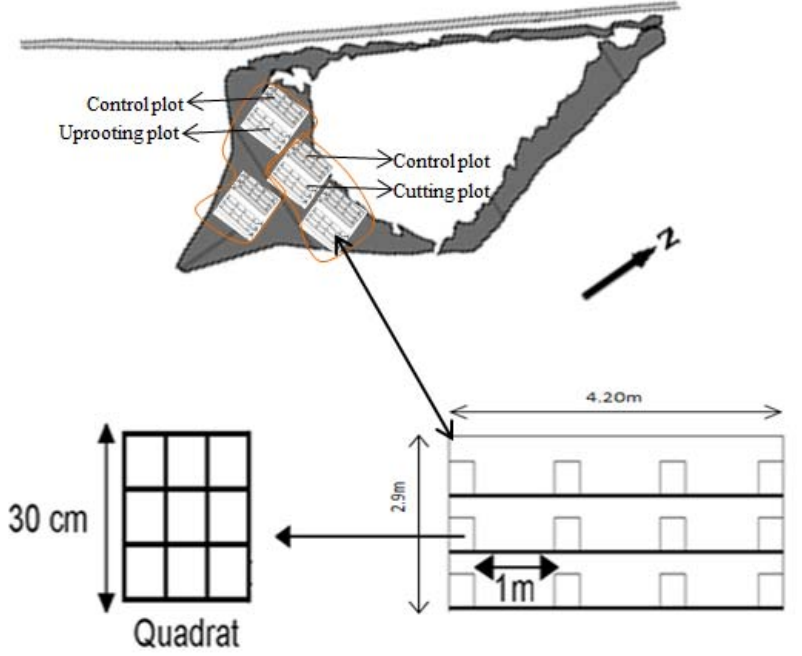

\section{EXPERIMENTAL (CUTTING VS. UPROOTING) SET UP}

Randomly within the rushes belt, four pairs of homogenous and neighbouring plots with two treatments were set up. A total of eight plots were assigned $(4.20 \times 2.90 \mathrm{~m})$ plots were $2 \mathrm{~m}$ apart, to one of the three treatments (control, cutting, or uprooting) (Fig. 3). Vegetation was monitored on $(30 \times 30 \mathrm{~cm})$ quadrats along the three permanent and parallel transects/plots (Fig. 3). Transects were $1 \mathrm{~m}$ apart. The number of quadrats per plot was 12 , spread over the three transects, with a total of 96 quadrats for the experiment. Cutting treatment: consisted of cutting the whole rushes stems at the sediment surface using a brush cutter,
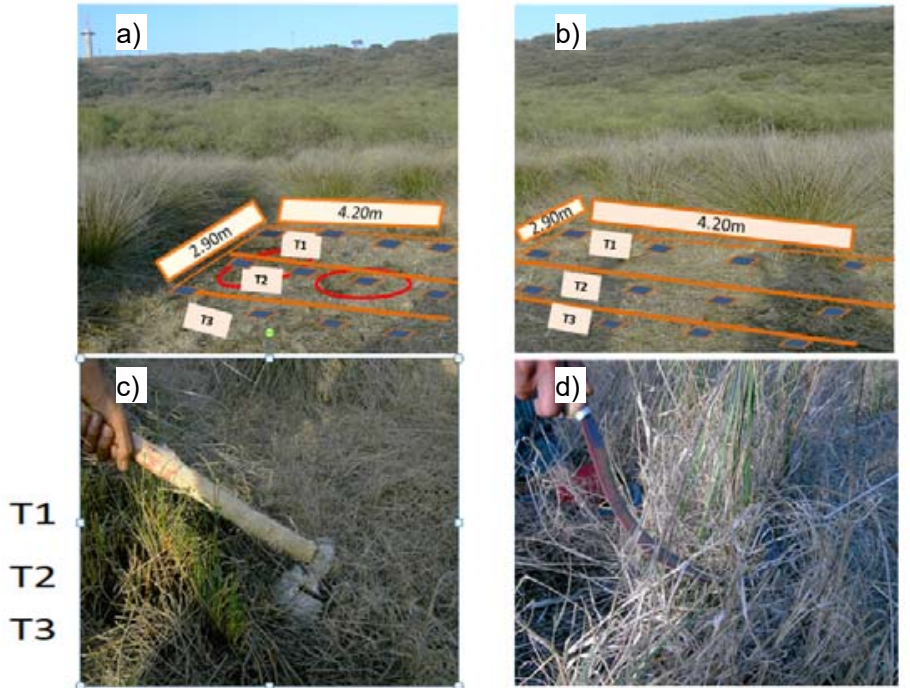

Fig. 3. Spatial distribution of the plots in the rush belt Juncus maritimus L. of the temporary wetland; four zones ( 2 treatments per zone with $4.20 \times 2.90 \mathrm{~m}$ ), vegetation was monitored on $30 \times 30 \mathrm{~cm}$ quadrats placed along permanent and parallel transects (T1, T2, T3) with a total of 96 quadrats; photos: a) uprooting plot, b) cutting plot, c) the proceeding of uprooting treatment after cutting of the rush stems followed by hand removal of all roots from the sediment red circles are showing created micro-cavities which remained flooded longer after root removal, d) the cutting treatment with brush cutter; source: own elaboration 
then removing biomass and all litter outside the plots. Uprooting treatment: consisted firstly of cutting off the rushes stems followed by hand removal of all roots from the sediment. Both treatments were applied at the start of the experiment (December 2011).

On each quadrat, the cover of each species was noted according to the Braun-Blanquet scale [KENT, COKER 1992]. Water depth (when present) was measured in each quadrat at each date over two years (2012 and 2013), with three visit dates per year (February, April, June). The quadrats were not flooded during the first year but were under maximum water heights of between 10 and $30 \mathrm{~cm}$ during the second year. Maximum water depths in quadrats in the $1^{\text {st }}$ year experiment, did not differ significantly between the four control zones $(p>0.05)$, but differed significantly between the three treatments (control, cutting, uprooting) $\left(\chi^{2}=14.40 ; \mathrm{df}=2, p=0.0007\right)$, with greater water heights in the uprooting and cutting treatments than in the control.

The abundance of each species was calculated at each monthly date (February, April, June) as was the frequency of that species in each quadrat. The abundance value used in data analysis was accumulated and a sum obtained across the different dates for each year. The species richness per plot was calculated as the accumulated sum of the species found across dates separately for each year. The annual or perennial trait (Tab. 1) was attributed for each species, following "Flora of North Africa" [MAIRE 19521987] consisting of sixteen volumes, and "Flora of Morocco" [FENNANE et al. 1999; 2007; 2014] consisting of three. The characteristic species of temporary wetlands (been defined as aquatic plants and amphibious ones), as well as the opportunistic species (been defined as terrestrial plants generally frequent in the surroundings) both have been identified following "Flora of North Africa" [MAIRE 19521987] and "Flora of Morocco" [FENNANE et al. 1999; 2007; 2014].

\section{STUDY OF SEED BANK/SPORE}

Within each of the 96 quadrats where vegetation was monitored, a $(4 \times 4 \mathrm{~cm})$ soil core targeting viable seeds [BONIS, LEPART 1994; LAVOREL et al. 1993] were sampled the first year of the experiment, after cutting and uprooting the rushes. In the laboratory, samples were weighed, soaked in water, and spread out on a layer of synthetic absorbent tissue on top of a $1 \mathrm{~cm}$ layer of washed and sterilized sand. The samples were arranged at random and watered daily. Once the seedlings emerged, they were identified, counted, and removed. Monitoring was performed weekly for the first four months, then monthly. After being kept dry for five months, the same samples were again submitted to the same germination conditions. For each sample, the seed density (total number of germinations per $1 \mathrm{~g}$ of sediment) was calculated.

\section{DATA ANALYSIS}

Differences in species richness (total, annuals, perennials and characteristic species) and species abundance (total, annuals, perennials and characteristic species) and differences in density and species richness in the seed stock (total, annuals, perennials and characteristic species) between treatments (control, cutting, uprooting) were analysed separately for each year using non-parametric Kruskal-Wallis tests. Comparisons by pair of treatments were performed. Difference in maximum water depths per quadrat between the four control zones, as well as between the three treatments (control, cut, uprooting), was studied by a nonparametric variance analysis Kruskal-Wallis. Correlation between the abundance of species (total, annuals, perennials, terrestrials and characteristic species) in vegetation and their abundance in the seed stock was tested by linear regressions performed separately for each treatment and each species group (JMP ${ }^{\mathrm{TM}}$ software).

A correspondence analysis (CA) was performed on the overall vegetation data during the two years of monitoring, taking into account (for each year, and each species) the maximum value of frequency (the frequency of each species was the maximum value found in sampling dates) recorded per quadrat. The CA was conducted with 39 species, excluding those found in less than four quadrats over the two years $(<0.5 \%$ of the total number of quadrats). The centroids of the distribution of the quadrants of each year were positioned on the $1 / 2$ biplot (Statistica 7.0).

\section{RESULTS}

\section{SPECIES RICHNESS AND ABUNDANCE RESPONSE TO CUTTING AND UPROOTING}

During the two cumulative years, 54 species were recorded in all quadrats, including 43 annuals (80\% of the total) and 11 perennials $(20 \%)$. A total of 41 species $(33$ annuals, 8 perennials) were found for control, 45 (37 annuals, 8 perennials) for the uprooting and 48 (39 annuals and 9 perennials) for the cutting (Tab. 1). The maximum water depth did not differ significantly between the four control zones $(p>0.05)$, but it was significantly different between the three treatments (control, cutting, uprooting) $\left(\chi^{2}=\right.$ $14.40 ; \mathrm{df}=2, p=0.0007)$; higher water was recorded in (uprooting and cutting) treatments than in the control one (Fig. 4).

Species richness. Total species richness per quadrat and annual species richness was significantly greater in the treated plots than in control area over the two years of the experiment (Tab. 2). Both richness of total and annual species were not significantly different $(p>0.05)$ in the first year between the two treatments (cutting and uprooting), the second year more species were recorded (total and annual) in the uprooting treatment than in the cutting (Tab. 2). Perennials richness was significantly different between the three treatments, showing lower values in the control plots the first year (Tab. 2). However, the richness of perennials did not show any significant difference between control and both treatments over the second year (Tab. 2).

Characteristic species richness increased significantly $(p<0.05)$ in cutting and uprooting plots compared to control areas for both years (Tab. 2, Fig. 5A). This richness was not significantly different between cutting and uproot- 
Table 1. List of recorded species during the experiment within each treatment over two years monitoring

\begin{tabular}{|c|c|c|c|c|c|c|}
\hline \multirow{2}{*}{ Species } & \multirow{2}{*}{ Code } & \multirow{2}{*}{$\begin{array}{l}\text { Annuals (A)/ } \\
\text { Perennial (V) }\end{array}$} & \multirow{2}{*}{$\begin{array}{l}\text { Characteristic } \\
\text { species }(\mathrm{m}) / \\
\text { Terrestrials }(\mathrm{t})\end{array}$} & \multicolumn{3}{|c|}{ Treatment } \\
\hline & & & & control & cutting & uprooting \\
\hline Agrostis pourretii Willd. & Ag.sal & A & $\mathrm{m}$ & $\mathrm{x}$ & $\mathrm{x}$ & $\mathrm{x}$ \\
\hline Ammi majus L. & Am.maj & $\mathrm{A}$ & $\mathrm{t}$ & $\mathrm{x}$ & $\mathrm{n}$ & $\mathrm{x}$ \\
\hline Anagallis arvensis $\mathrm{L}$. & An.arv & $\mathrm{A}$ & $\mathrm{t}$ & $\mathrm{x}$ & $\mathrm{x}$ & $\mathrm{n}$ \\
\hline Atriplex prostrata Boucher. & At.pro & A & $\mathrm{m}$ & $\mathrm{n}$ & $\mathrm{x}$ & $\mathrm{x}$ \\
\hline Bellis annua $\mathrm{L}$. & Be.ann & A & $\mathrm{t}$ & $\mathrm{x}$ & $\mathrm{x}$ & $\mathrm{n}$ \\
\hline Bolboschoenus maritimus $\mathrm{L}$. & Sc.mar & $\mathrm{V}$ & $\mathrm{m}$ & $\mathrm{x}$ & $\mathrm{x}$ & $\mathrm{x}$ \\
\hline Briza minor $\mathrm{L}$. & Br.min & $\mathrm{A}$ & $\mathrm{t}$ & $\mathrm{x}$ & $\mathrm{x}$ & $\mathrm{x}$ \\
\hline Calendula arvensis $\mathrm{L}$. & Ca.alg & $\mathrm{A}$ & $\mathrm{t}$ & $\mathrm{x}$ & $\mathrm{x}$ & $\mathrm{x}$ \\
\hline Chara canescens Desv. \& Lois. & Chara & $\mathrm{A}$ & $\mathrm{m}$ & $\mathrm{n}$ & $\mathrm{x}$ & $\mathrm{x}$ \\
\hline Chenopodium chenopodioides (L.) Aellen. & Ch.che & $\mathrm{A}$ & $\mathrm{m}$ & $\mathrm{x}$ & $\mathrm{x}$ & $\mathrm{x}$ \\
\hline Cynodon dactylon $\mathrm{L}$. & Cy.dac & $\mathrm{V}$ & $\mathrm{t}$ & $\mathrm{n}$ & $\mathrm{x}$ & $\mathrm{x}$ \\
\hline Daucus crinitus Desf. & Da.cri & $\mathrm{V}$ & $\mathrm{t}$ & $\mathrm{x}$ & $\mathrm{x}$ & $\mathrm{x}$ \\
\hline Diplotaxis catholica (L.) DC. & Di.cat & $\mathrm{A}$ & $\mathrm{t}$ & $\mathrm{x}$ & $\mathrm{x}$ & $\mathrm{x}$ \\
\hline Echium plantagineum $\mathrm{L}$. & Ec.pla & $\mathrm{V}$ & $\mathrm{t}$ & $\mathrm{x}$ & $\mathrm{x}$ & $\mathrm{x}$ \\
\hline Erodium cicutarium $\mathrm{L}$. & Er.cic & A & $\mathrm{t}$ & $\mathrm{x}$ & $\mathrm{x}$ & $\mathrm{n}$ \\
\hline Euphorbia exigua L. & Eu.exi & $\mathrm{A}$ & $\mathrm{t}$ & $\mathrm{x}$ & $\mathrm{x}$ & $\mathrm{n}$ \\
\hline Exaculum pusillum (Lam.) Caruel. & Ex.pus & $\mathrm{A}$ & $\mathrm{m}$ & $\mathrm{n}$ & $\mathrm{n}$ & $\mathrm{x}$ \\
\hline Filago gallica $\mathrm{L}$ & Fi.gal & A & $\mathrm{t}$ & $\mathrm{n}$ & $\mathrm{x}$ & $\mathrm{x}$ \\
\hline Frankenia laevis $\mathrm{L}$. & Fr.lae & $\mathrm{V}$ & $\mathrm{m}$ & $\mathrm{x}$ & $\mathrm{x}$ & $\mathrm{x}$ \\
\hline Fumaria agraria Lag. & Fu.agr & $\mathrm{A}$ & $\mathrm{t}$ & $\mathrm{x}$ & $\mathrm{x}$ & $\mathrm{x}$ \\
\hline Gaudinia fragilis (L.) P.Beauv. & Ga.fra & $\mathrm{A}$ & $\mathrm{t}$ & $\mathrm{x}$ & $\mathrm{x}$ & $\mathrm{x}$ \\
\hline Geranium molle L. & Ge.mol & $\mathrm{A}$ & $\mathrm{t}$ & $\mathrm{x}$ & $\mathrm{x}$ & $\mathrm{x}$ \\
\hline Glyceria fluitans (L.) R.Br. & Gl.flu & $\mathrm{V}$ & $\mathrm{m}$ & $\mathrm{x}$ & $\mathrm{x}$ & $\mathrm{x}$ \\
\hline Hedypnois cretica (L.) Dum. Cours. & Hy.cre & A & $\mathrm{t}$ & $\mathrm{x}$ & $\mathrm{x}$ & $\mathrm{x}$ \\
\hline Hordeum maritimum Hudson. & Ho.mar & $\mathrm{A}$ & $\mathrm{m}$ & $\mathrm{x}$ & $\mathrm{x}$ & $\mathrm{x}$ \\
\hline Isolepis cernua (Vahl) Roem. \& Schult. & Is.cer & $\mathrm{A}$ & $\mathrm{m}$ & $\mathrm{n}$ & $\mathrm{x}$ & $\mathrm{n}$ \\
\hline Juncus bufonius L. & Ju.buf & A & $\mathrm{m}$ & $\mathrm{x}$ & $\mathrm{x}$ & $\mathrm{x}$ \\
\hline Juncus maritimus L. & Ju.mar & $\mathrm{V}$ & $\mathrm{m}$ & $\mathrm{x}$ & $\mathrm{x}$ & $\mathrm{n}$ \\
\hline Juncus pygmaeus Richard & Ju.pyg & A & $\mathrm{m}$ & $\mathrm{n}$ & $\mathrm{x}$ & $\mathrm{x}$ \\
\hline Leontodon taraxacoides (Vill.) Merat. & Le.tar & $\mathrm{V}$ & $\mathrm{t}$ & $\mathrm{n}$ & $\mathrm{x}$ & $\mathrm{x}$ \\
\hline Lolium rigidum Gaudin. & Lo.rig & A & $\mathrm{t}$ & $\mathrm{x}$ & $\mathrm{x}$ & $\mathrm{x}$ \\
\hline Lotus hispidus DC.s & Lo.his & A & $\mathrm{m}$ & $\mathrm{x}$ & $\mathrm{x}$ & $\mathrm{x}$ \\
\hline Lythrum junceum Banks \& Solander & Ly.jun & $\mathrm{V}$ & $\mathrm{m}$ & $\mathrm{x}$ & $\mathrm{x}$ & $\mathrm{x}$ \\
\hline Malva hispanica $\mathrm{L}$. & Ma.his & $\mathrm{A}$ & $\mathrm{t}$ & $\mathrm{n}$ & $\mathrm{x}$ & $\mathrm{x}$ \\
\hline Medicago polymorpha $\mathrm{L}$. & Me.pol & A & $\mathrm{t}$ & $\mathrm{x}$ & $\mathrm{x}$ & $\mathrm{x}$ \\
\hline Mercurialis anпиа $\mathrm{L}$. & Me.ann & A & $\mathrm{t}$ & $\mathrm{x}$ & $\mathrm{x}$ & $\mathrm{x}$ \\
\hline Nitella opaca $\mathrm{Ag}$. & Nitella & $\mathrm{A}$ & $\mathrm{m}$ & $\mathrm{x}$ & $\mathrm{x}$ & $\mathrm{x}$ \\
\hline Cladanthus mixtus (L.) Chevall. & An.mix & A & $\mathrm{t}$ & $\mathrm{x}$ & $\mathrm{x}$ & $\mathrm{n}$ \\
\hline Plantago coronopus L. & Pl.cor & A & $\mathrm{t}$ & $\mathrm{n}$ & $\mathrm{n}$ & $\mathrm{x}$ \\
\hline Polypogon monspeliensis (L.) Desf. & Po.mon & A & $\mathrm{m}$ & $\mathrm{x}$ & $\mathrm{x}$ & $\mathrm{x}$ \\
\hline Ranunculus baudotii Schrank. & Ra.bau & A & $\mathrm{m}$ & $\mathrm{x}$ & $\mathrm{x}$ & $\mathrm{x}$ \\
\hline Ranunculus sardous Crantz. & Ra.sa & A & $\mathrm{m}$ & $\mathrm{x}$ & $\mathrm{x}$ & $\mathrm{x}$ \\
\hline Rubia peregrina $\mathrm{L}$. & Ru.per & $\mathrm{V}$ & $\mathrm{t}$ & $\mathrm{x}$ & $\mathrm{n}$ & $\mathrm{n}$ \\
\hline Rumex crispus $\mathrm{L}$. & Ru.cri & $\mathrm{V}$ & $\mathrm{m}$ & $\mathrm{n}$ & $\mathrm{x}$ & $\mathrm{x}$ \\
\hline Rumex pulcher $\mathrm{L}$. & Ru.pul & $\mathrm{V}$ & $\mathrm{m}$ & $\mathrm{n}$ & $\mathrm{x}$ & $\mathrm{n}$ \\
\hline Salicornia herbacea L. & Sa.her & A & $\mathrm{m}$ & $\mathrm{x}$ & $\mathrm{x}$ & $\mathrm{x}$ \\
\hline Sanguisorba minor Scop. & Sa.min & $\mathrm{V}$ & $\mathrm{t}$ & $\mathrm{x}$ & $\mathrm{n}$ & $\mathrm{x}$ \\
\hline Spergularia salina J. Presl \& C. Presl. & Sp.sal & $\mathrm{A}$ & $\mathrm{m}$ & $\mathrm{x}$ & $\mathrm{n}$ & $\mathrm{x}$ \\
\hline Stellaria media (L.) Vill. & St.med & $\mathrm{A}$ & $\mathrm{t}$ & $\mathrm{x}$ & $\mathrm{x}$ & $\mathrm{x}$ \\
\hline Tolpis barbata (L.) Gaertn. & To.bar & $\mathrm{A}$ & $\mathrm{t}$ & $\mathrm{x}$ & $\mathrm{x}$ & $\mathrm{x}$ \\
\hline Trifolium michelianum $\mathrm{L}$. & Tr.mic & A & $\mathrm{t}$ & $\mathrm{x}$ & $\mathrm{x}$ & $\mathrm{x}$ \\
\hline Trifolium repens $\mathrm{L}$. & Tr.rep & A & $\mathrm{t}$ & $\mathrm{x}$ & $\mathrm{x}$ & $\mathrm{x}$ \\
\hline Urospermum picroides (L.) Scop. & Ur.pic & $\mathrm{A}$ & $\mathrm{t}$ & $\mathrm{x}$ & $\mathrm{x}$ & $\mathrm{x}$ \\
\hline Urtica dioica $\mathrm{L}$. & Ur.dio & $\mathrm{A}$ & $\mathrm{t}$ & $\mathrm{n}$ & $\mathrm{x}$ & $\mathrm{x}$ \\
\hline Total number of species & 54 & & & 41 & 48 & 45 \\
\hline
\end{tabular}

Explanations: $\mathrm{x}=$ recorded, $\mathrm{n}=$ not-recorded.

Source: own study, the identification of species was based on MAIRE [1952-1987] and FENNANE et al. [1999; 2007; 2014]. 
Table 2. Kruskall-Wallis results comparing the abundance and species richness (total, annuals, perennials, characteristics and terrestrials) between treatments (control: T; cutting: C; uprooting: E) over the $1^{\text {st }}$ and $2^{\text {nd }}$ monitoring year $(\mathrm{df}=2)$

\begin{tabular}{|c|c|c|c|c|c|c|c|c|c|}
\hline \multirow{2}{*}{$\begin{array}{c}\text { Monitoring } \\
\text { years }\end{array}$} & \multirow{2}{*}{ Description } & \multicolumn{4}{|c|}{ Richness } & \multicolumn{4}{|c|}{ Abundance } \\
\hline & & $\chi^{2}$ & $p$ & median value & comparison & $\chi^{2}$ & $p$ & median values & comparison \\
\hline \multirow{5}{*}{$1^{\text {st }}$ year } & total & 50.69 & $<0.001$ & $10.5^{\mathrm{a}} ; 9^{\mathrm{a}} ; 2^{\mathrm{b}}$ & $\mathrm{E}^{\mathrm{a}} \mathrm{C}^{\mathrm{a}} \mathrm{T}^{\mathrm{b}}$ & 38.03 & $<0.001$ & $27^{\mathrm{a}} ; 25.5^{\mathrm{a}} ; 9^{\mathrm{b}}$ & $\mathrm{C}^{\mathrm{a}} \mathrm{E}^{\mathrm{a}} \mathrm{T}^{\mathrm{b}}$ \\
\hline & annuals & 50.09 & $<0.001$ & $8.5^{\mathrm{a}} ; 6.5^{\mathrm{a}} ; 1^{\mathrm{b}}$ & $\mathrm{E}^{\mathrm{a}} \mathrm{C}^{\mathrm{a}} \mathrm{T}^{\mathrm{b}}$ & 51.10 & $<0.001$ & $22.5^{\mathrm{a}} ; 22^{\mathrm{a}} ; 10.5^{\mathrm{b}}$ & $\mathrm{E}^{\mathrm{a}} \mathrm{C}^{\mathrm{a}} \mathrm{T}^{\mathrm{b}}$ \\
\hline & perennials & 6.36 & $<0.01$ & $2^{\mathrm{a}} ; 2^{\mathrm{a}} ; 1^{\mathrm{b}}$ & $C^{a} E^{a} T^{b}$ & 6.71 & $<0.01$ & $9^{\mathrm{a}} ; 8^{\mathrm{a}} ; 6^{\mathrm{b}}$ & $\mathrm{T}^{\mathrm{a}} \mathrm{C}^{\mathrm{a}} \mathrm{E}^{\mathrm{b}}$ \\
\hline & characteristics & 28.93 & $<0.001$ & $4^{\mathrm{a}} ; 4^{\mathrm{a}} ; 2.9^{\mathrm{b}}$ & $\mathrm{E}^{\mathrm{a}} \mathrm{C}^{\mathrm{a}} \mathrm{T}^{\mathrm{b}}$ & 21.16 & $<0.001$ & $14^{\mathrm{a}} ; 12.25^{\mathrm{a}} ; 6.5^{\mathrm{b}}$ & $\mathrm{E}^{\mathrm{a}} \mathrm{C}^{\mathrm{a}} \mathrm{T}^{\mathrm{b}}$ \\
\hline & terrestrials & 30.51 & $<0.001$ & $3.5^{\mathrm{a}} ; 3^{\mathrm{a}}, 3^{\mathrm{b}}$ & $\mathrm{C}^{\mathrm{a}} \mathrm{E}^{\mathrm{a}} \mathrm{T}^{\mathrm{b}}$ & 19.70 & $<0.001$ & $19^{\mathrm{a}} ; 15^{\mathrm{a}} ; 10^{\mathrm{b}}$ & $C^{a} E^{a} T^{b}$ \\
\hline \multirow{5}{*}{$2^{\text {nd }}$ year } & total & 70.00 & $<0.001$ & $13^{\mathrm{a}} ; 12.5^{\mathrm{b}} ; 6^{\mathrm{c}}$ & $\mathrm{E}^{\mathrm{a}} \mathrm{C}^{\mathrm{b}} \mathrm{T}^{\mathrm{c}}$ & 64.75 & $<0.001$ & $33.5^{\mathrm{a}} ; 32^{\mathrm{b}} ; 11^{\mathrm{c}}$ & $\mathrm{E}^{\mathrm{a}} \mathrm{C}^{\mathrm{b}} \mathrm{T}^{\mathrm{c}}$ \\
\hline & annuals & 71.50 & $<0.001$ & $10^{\mathrm{a}} ; 9^{\mathrm{b}} ; 4^{\mathrm{c}}$ & $\mathrm{E}^{\mathrm{a}} \mathrm{C}^{\mathrm{b}} \mathrm{T}^{\mathrm{c}}$ & 71.30 & $<0.001$ & $26.5^{\mathrm{a}} ; 22^{\mathrm{b}} ; 7^{\mathrm{c}}$ & $\mathrm{E}^{\mathrm{a}} \mathrm{C}^{\mathrm{b}} \mathrm{T}^{\mathrm{c}}$ \\
\hline & perennials & 1.87 & 0.47 & $3^{\mathrm{a}} ; 3^{\mathrm{a}} ; 3^{\mathrm{a}}$ & $\mathrm{T}^{\mathrm{a}} \mathrm{C}^{\mathrm{a}} \mathrm{E}^{\mathrm{a}}$ & 14.56 & $<0.001$ & $11^{\mathrm{a}} ; 8.5^{\mathrm{b}} ; 8.5^{\mathrm{b}}$ & $T^{a} C^{b} E^{b}$ \\
\hline & characteristics & 40.94 & $<0.001$ & $6^{\mathrm{a}} ; 5^{\mathrm{b}} ; 3^{\mathrm{c}}$ & $\mathrm{E}^{\mathrm{a}} \mathrm{C}^{\mathrm{b}} \mathrm{T}^{\mathrm{c}}$ & 20.69 & $<0.001$ & $19^{\mathrm{a}} ; 13,5^{\mathrm{b}} ; 10^{\mathrm{c}}$ & $\mathrm{E}^{\mathrm{a}} \mathrm{C}^{\mathrm{b}} \mathrm{T}^{\mathrm{c}}$ \\
\hline & terrestrials & 78.65 & $<0.001$ & $7.5^{\mathrm{a}} ; 6.5^{\mathrm{a}} ; 1^{\mathrm{b}}$ & $\mathrm{E}^{\mathrm{a}} \mathrm{C}^{\mathrm{a}} \mathrm{T}^{\mathrm{b}}$ & 77.85 & $<0.001$ & $20^{\mathrm{a}} ; 18.5^{\mathrm{b}} ; 16^{\mathrm{b}}$ & $E^{a} C^{a} T^{b}$ \\
\hline
\end{tabular}

Explanations: different letters on median values and their comparison represent significant difference between treatments $(p<0.05)$. Source: own study.

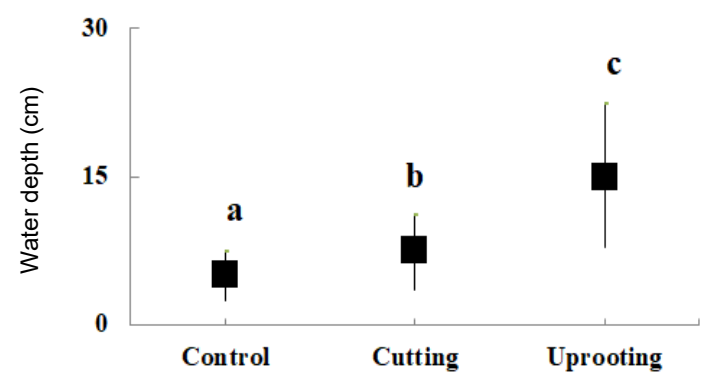

Fig. 4. Comparison of water depth recorded between treatments (control, cutting and uprooting) over the second year monitoring; on the graphs are represented the medians the minimum and maximum for each treatment; the different letters on the graph indicate a significant difference between treatments $(p<0.05)$; source: own study

ing during the first year but increased significantly in the second year (Tab. 2). The terrestrial richness was significantly greater in the cutting and uprooting plots compared to controls over the two years of monitoring (Tab. 2). Terrestrials' richness did not show a significant difference between cutting and uprooting $(p>0.05)$ over the two years (Tab. 2). Total richness per quadrant was correlated to the maximum depth of water in the second year $\left(r^{2}=0.30, p<0.0001, n=96\right)$. This correlation was greater for the richness of characteristics $\left(r^{2}=0.40, p<0.0001\right.$, $n=96)$ compared to terrestrial richness $\left(r^{2}=0.10\right.$, $p=0.01, n=96)$.

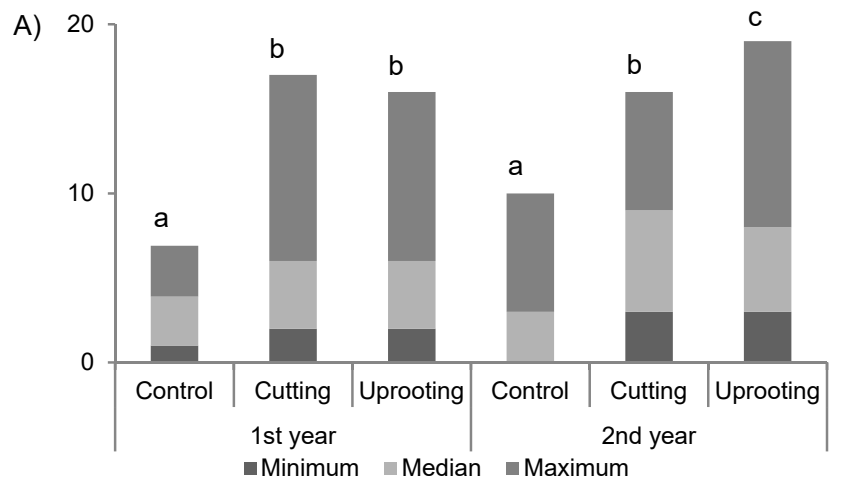

Species abundance. Total species abundance per quadrat and annuals abundance were significantly greater in the treated plots than in control during the two years experiment (Tab. 2). Their abundance had significantly increased in uprooting plots during the second year (Tab. 2). The abundance of perennials was significantly lower in the uprooting plots than in the cutting and control plots during the first year. Cutting and control plots did not show any significant change (Tab. 2) in the second year. The abundance of perennials was significantly lower both in the uprooting and cut plots, compared to control, with a small difference between cutting and uprooting (Tab. 2). The abundance and richness of characteristic species had increased more and significantly both in experimental and control plots during the two years experiment (Tab. 2; Fig 5A, 5B). Their abundance was not significantly different between the cut and uprooting in the first year but had increased significantly the following year in uprooting (Tab. 2 ). The abundance of terrestrial species was significantly higher in the experimental plots than in the controls during the two-year experiment (Tab. 2), but with no significant difference between cutting and uprooting treatments (Tab. 2 ). The total vegetation abundance was significantly correlated with the maximum water depth $\left(r^{2}=0.32\right.$, $p<0.0001, n=96)$. This correlation was greater for the abundance of characteristic species $\left(r^{2}=0.35, p<0.0001\right.$, $n=96)$ compared to the abundance of terrestrials $\left(r^{2}=0.1\right.$; $p=0.01 ; n=96)$.

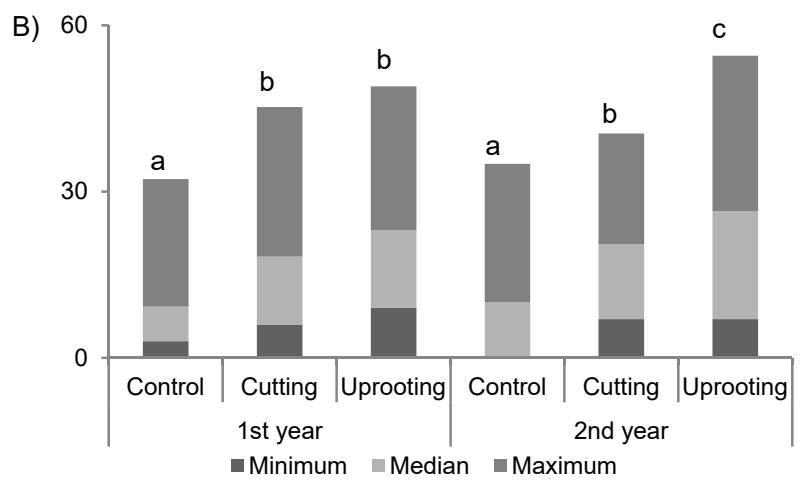

Fig. 5. Comparison of characteristic species richness (A) and abundance (B) between treatments (control, cutting and uprooting), separately for each year monitoring; on the graphs are represented the minimum, the medians and maximum for each treatment; the different letters on the graph indicate a significant difference between treatments $(p<0.05)$; source: own study 


\section{EFFECT OF CUTTING AND UPROOTING ON SEED STOCK DENSITY AND RICHNESS}

During the germination trial of soil samples cored from the quadrats, a total number of 8876 germinations occurred 1621 established in cutting treatment, 1923 in uprooting and 5232 in control). 27 species were identified (24 annuals and 3 perennials) a number of 17 species occurred in the uprooting treatment (14 annuals and 3 perennials) 21 species in the cutting treatment (17 annuals and 4 perennials) and 25 species occurred in the control (19 annuals and perennials). The seed bank was mainly dominated by Juncus maritimus (Lam.) (34\% of total seedlings), Polypogon monspeliensis (L.) Desf (25\% of total seedling), Anagallis arvensis (L.) (11\% of total seedling), Juncus pygmaeus (Rich.) (10\% of total seedling) and Chenopodium chenopodioides (L.) Aellen. (4\% of total seedling).

Seed stock density and richness. The density of the seed stock (total, annuals and terrestrials) was significantly higher in the control area, but showed no difference between cutting and uprooting treatments. On the other hand, no significant difference of the density of perennials was recorded (Tab. 3). While seed density of characteristic species was significantly different between the three treatments, but remained higher in control (Tab. 3). The total richness of seed stock, as well as annuals richness, was significantly different $(p<0.05)$ between control, uprooting and cutting. They were higher for the control but greater in the cutting treatment (Tab. 3), perennials showed no significant difference between treatments (Tab. 3).

Correlation between vegetation/seed stock within treatments.

During the two years of monitoring, the correlation between vegetation and seed stock ranged between treat- ments with an $r^{2}$ value ranging from 0.03 to 0.96 (Tab. 4). Seeds/vegetation correlation was not significant for the total species among control as well as annuals, characteristics and terrestrials but significant for perennials (Tab. 4). The cutting treatment showed the same correlation seed/ vegetation for perennials. Concerning the uprooting treatment, the correlation between vegetation and seed stock was significant for the total number of species, the annuals, the characteristics, and terrestrials, but not significant for the perennials (Tab. 4).

Post-treatment temporal community dynamic. The first two axes of correspondence analysis (CA) account for $54.16 \%$ of the total variance (Fig. $6 \mathrm{~A}) . \mathrm{F}_{1}$ axis $(39.47 \%$ of variance) opposes characteristics of temporary considered as aquatic species Ranunculus baudotii Schrank., Glyceria fluitans (L.) R.Br., and terrestrial species Anagallis arvensis L., Hordeum maritimum Hudson. $\mathrm{F}_{2}$ axis (14.69\% of variance) opposes treatments (cutting and uprooting) with low abundance of vegetation and control areas with high abundance. The coordinates of centroids of quadrats on $F_{1}$ axis were correlated with the maximum depth of water $\left(r^{2}=0.97, p=0.004, n=96\right)$. The coordinates of vegetation quadrats on the $\mathrm{F}_{2}$ axis of the CA were significantly correlated (Fig. 6A). With the total abundance of species per quadrat $\left(r^{2}=0.93, p=0.0016, n=96\right)$.

The annual centroids displacement of treatments (control, cutting, uprooting) on the $1 / 2$ biplot of the CA was more important for uprooting treatment compared to cutting. While it was lower for the control (Fig. 6B), the displacement was along the $\mathrm{F}_{2}$ axis for the uprooting and the cutting, reflecting an increase in vegetation abundance during the two years monitoring, but along the $F_{1}$ axis for the control treatment reflecting an increase in the number of terrestrial species (Fig. 6B).

Table 3. Kruskall-Wallis results comparing seed stock density and richness (total, annuals, perennials, characteristics and terrestrials) between treatments $(\mathrm{df}=2)$

\begin{tabular}{|c|c|c|c|c|c|c|c|c|}
\hline \multirow{2}{*}{ Description } & \multicolumn{4}{|c|}{ Density } & \multicolumn{4}{|c|}{ Richness } \\
\hline & $\chi^{2}$ & $p$ & median value & comparison & $\chi^{2}$ & $p$ & median value & comparison \\
\hline Total & 16.98 & $<0.001$ & $1.32^{\mathrm{a}} ; 0.88^{\mathrm{b}} ; 0.75^{\mathrm{b}}$ & $T^{a} E^{b} C^{b}$ & 9.15 & $<0.01$ & $7^{\mathrm{a}} ; 6.5^{\mathrm{b}} ; 5^{\mathrm{c}}$ & $\mathrm{T}^{\mathrm{a}} \mathrm{C}^{\mathrm{b}} \mathrm{E}^{\mathrm{c}}$ \\
\hline Annuals & 16.89 & $<0.001$ & $1.32^{\mathrm{a}} ; 0.88^{\mathrm{b}} ; 0.75^{\mathrm{b}}$ & $T^{a} E^{b} C^{b}$ & 9.71 & $<0.001$ & $7^{\mathrm{a}} ; 6.5^{\mathrm{b}} ; 5^{\mathrm{c}}$ & $T^{a} C^{b} E^{c}$ \\
\hline Perennials & 1.87 & 0.39 & $0^{\mathrm{a}} ; 0^{\mathrm{a}} ; 0^{\mathrm{a}}$ & $T^{a} E^{a} C^{a}$ & 1.87 & 0.39 & $0^{\mathrm{a}} ; 0^{\mathrm{a}} ; 0^{\mathrm{a}}$ & $\mathrm{T}^{\mathrm{a}} \mathrm{C}^{\mathrm{a}} \mathrm{E}^{\mathrm{a}}$ \\
\hline Characteristics & 14.98 & $<0.001$ & $0.91^{\mathrm{a}}: 0.61^{\mathrm{b}}: 0.42^{\mathrm{b}}$ & $T^{a} E^{b} C^{b}$ & 5.87 & $<0.01$ & $4^{\mathrm{a}}: 4^{\mathrm{a}}: 3^{\mathrm{b}}$ & $T^{a} C^{a} E^{b}$ \\
\hline Terrestrials & 9.10 & $<0.01$ & $0.45^{\mathrm{a}} ; 0.3^{\mathrm{b}} ; 0.23^{\mathrm{b}}$ & $\mathrm{T}^{\mathrm{a}} \mathrm{C}^{\mathrm{b}} \mathrm{E}^{\mathrm{b}}$ & 6.74 & $<0.01$ & $3^{\mathrm{a}} ; 2^{\mathrm{b}} ; 2^{\mathrm{b}}$ & $T^{a} C^{b} E^{b}$ \\
\hline
\end{tabular}

Explanations: $\mathrm{T}=$ control, $\mathrm{C}=$ cutting, $\mathrm{E}=$ uprooting; different letters on median values and their comparison represent significant difference between treatments $(p<0.05)$.

Source: own study.

Table 4. Correlation between the abundance of species (total, annuals, perennials, characteristics and terrestrials) in the aboveground vegetation and seed stock density for the three treatments (control, cutting, uprooting)

\begin{tabular}{|c|c|c|c|c|c|c|c|c|c|c|c|c|c|c|c|}
\hline \multirow{2}{*}{ Treatment } & \multicolumn{3}{|c|}{ Total abundance } & \multicolumn{3}{|c|}{ Annuals abundance } & \multicolumn{3}{|c|}{ Perennials abundance } & \multicolumn{3}{|c|}{ Characteristics abundance } & \multicolumn{3}{|c|}{ Terrestrials abundance } \\
\hline & $r^{2}$ & $p$ & $n$ & $r^{2}$ & $p$ & $n$ & $r^{2}$ & $p$ & $n$ & $r^{2}$ & $p$ & $n$ & $r^{2}$ & $p$ & $n$ \\
\hline Control & 0.20 & 0.08 & 43 & 0.06 & 0.85 & 35 & 0.82 & 0.009 & 8 & 0.03 & 0.2 & 19 & 0.13 & 0.2 & 24 \\
\hline Cutting & 0.17 & 0.17 & 46 & 0.16 & 0.35 & 37 & 0.96 & 0.0001 & 9 & 0.16 & 0.3 & 21 & 0.11 & 0.4 & 25 \\
\hline Uprooting & 0.37 & 0.009 & 52 & 0.35 & 0.01 & 42 & 0.44 & 0.32 & 10 & 0.21 & 0.008 & 22 & 0.57 & 0.006 & 30 \\
\hline
\end{tabular}

Explanations: $r^{2}=$ determination coefficient, $n=$ total number of observations of species abundance.

Source: own study. 

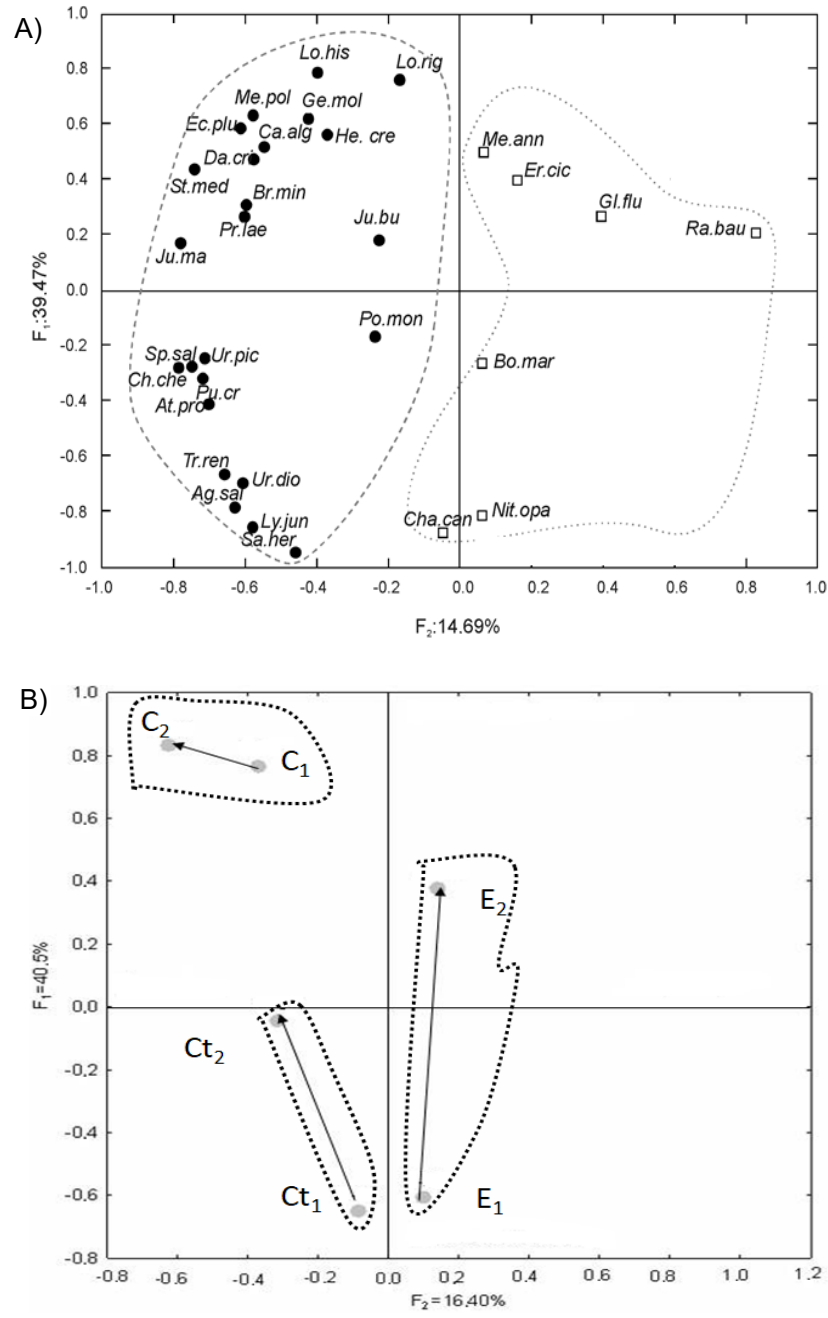

Fig. 6. Plot $1 / 2$ of the CA with the positioning of centroids of vegetation axis 1 opposes characteristics and terrestrials; axis 2 opposes high abundance and low abundance (species code in

Table 1) (A) and plot $1 / 2$ of the CA over the two years monitoring with the positioning of centroids of each year; $\mathrm{C}_{1}, \mathrm{Ct}_{1}, \mathrm{E}_{1}$ : control, cutting, uprooting first year post treatment respectively and $\mathrm{C}_{2}, \mathrm{Ct}_{2}, \mathrm{E}_{2}$ : control, cutting, second year post treatment uprooting respectively axis 1 opposes characteristics and terrestrials axis 2 opposes high abundance and low abundance (B); source: own study

\section{DISCUSSION}

Both the cutting and uprooting the rushes Juncus maritimus (Lam.) had significantly increased the richness and abundance of the species (total, annuals, and characteristics). Since the first year experiment, showing that the reduction of heavy biomasses of high competitors favours the recruitment and installation of fewer competitor species [BARBARO et al. 2001; ERWIN, WETZEL 2002; KAHMEN et al. 2002]. Cutting followed by biomass removal was found in other ecosystems in Europe such as montane fen meadow [BILLETER et al. 2007] and grassland [WAHLMAN, MiLBERG 2002], as an efficient technique for restoring and conserving the biodiversity.

Over the second-year experiment, this increase was greater in the uprooted plots than in cut ones (Tab. 2), probably as a result of the maximum water depth that was significantly higher in the uprooted plots than in the cut ones (Fig. 4). This could be explained by the creation of micro-cavities during root removal that remained flooded longer, favouring the establishment of many species [JANSEN, ROELOFS 1996] particularly characteristic species of the temporary wetlands (e.g. Chara canescens Desv. \& Lois., Juncus pygmaeus (Rich.), Exaculum pusillum (Lam.) Caruel.). The significant correlations found between species richness/maximum water depth on the one hand, and species abundance/maximum water depth, on the other hand, could confirm this hypothesis. Compared to terrestrials $\left(r^{2}=0.10\right)$, characteristic species were more favoured by these hydrological conditions $\left(r^{2}=0.35\right)$. The result joins many studies that highlight the importance of environmental variables, particularly hydrology, in the restoration of communities in wetlands [KERCHER, ZEDLER 2004; ZEDLER 2000].

Furthermore the long-term study conducted by KOLOS and BANASZAK [2013] emphasizes that cutting must be accompanied by appropriate hydrological conditions, among which flooding is of great importance, otherwise cutting cannot be adequate to suppress rushes and ensure the restoration of species richness on wetlands meadows. Species recruitment would be mainly linked to some release of the local seed stock; while the role of colonisation from neighbouring sites would be reduced given the limitation of particular mechanisms for dispersal. The increase of species richness and abundance of the characteristic species of the temporary wetlands after cutting and uprooting rushes Juncus maritimus (Lam.) is an indicator of the success of their restoration. This result, obtained over a twoyear monitoring period is likely to change over the short periods of time because of the rapid development of macrophytes. To cope with the problem, a repeated annual monitoring of the use of the land will be required, as it would reduce rushes dominance [LISHAWA et al. 2015]. Indeed, GÜSEWELL et al. [2000] had shown the main role of both frequency and timing of mowing for the success of restoration; this is due to tolerance of macrophytes to mechanical handling [DEER 2008]. The increase of mowing frequency can be counterproductive leading to a decrease in the number of targeted species, reducing flowering and fructification [FYNN et al. 2004].

\section{EFFECT OF CUTTING AND UPROOTING ON THE SEED STOCK}

It has been proven that the seed stock needs an investigation period before any restoration intervention; the seed stock of the temporary wetland is dominated by typical wetlands species (Juncus pygmaeus (Rich.) Fourr., Polypogon monspeliensis (L.) Desf., Juncus maritimus (Lam.), Chenopodium chenopodioides (L.) Aellen.) representing $73 \%$ of the total stock. Terrestrial species were poorly represented. Indeed, in unpredictable habitats such as temporary wetlands, the characteristic species are adapted to the fluctuating conditions of the hydrology by producing sustainable buried seeds [BROCK, CROSSLÉ 2002]. Seed stock buffers the effect of repeated establishment failure during dry years [BONIS 1993]. The availability of a high density of seeds of the characteristic species of the temporary wet- 
lands eases the restoration of characteristic communities. Indeed, the importance of seed availability for wetland restoration has been highlighted in many studies as a key element of its success [BISCHOFF 2002; ERVIN, WETZEL 2002; LINDIG-CiSNEROS, ZEDLER 2002; UnGAR 2001; ZEDLER 2000]. Seed stock also plays an important role in the resilience of temporary wetlands [BROCK 1998]. Our study shows that both the density and richness of the seed stock were three times greater in the control plots than in the cutting and uprooting plots (Tab. 3). Both treatments (uprooting and cutting) reduced significantly the density and total richness of the seed stock. In the case of uprooting this is probably linked to root removal (root were 50 to $60 \mathrm{~cm}$ deep), whereas for cutting it is probably due to the above ground biomass cleaning after the cut. Both methods had a simultaneous seed stock decrease as side effect. However, the expected result was a non-significant effect of rushes cutting on total seed density. The obtained effect (Tab. 3) would probably be related to the deep cleaning of experimental plots (removal of all litter above ground after cutting), which would have eliminated many seeds out of the plots. Although, the cut did not affect the richness of characteristic species of the temporary wetlands in seed stock, their richness was not different in cut plots compared to control (Tab. 3) On the other hand, uprooting had significantly reduced their richness probably in relation with the deep disturbance of the soil stratification and the bottom-up movement of the seed layers.

\section{SEED STOCK/VEGETATION CORRELATION}

Poor seed stock conditions suggest, poor vegetation reintroduction, it is likely to potentially block species recovery in temporary wetland community. Correlation between vegetation and seed stock over the two years in the plots was studied by linear regressions carried out separately on each group of species. Results showed that in the uprooted plots the abundance of all species (total, annuals, characteristics and terrestrials) in the vegetation was significantly correlated to their density in the seed stock. This correlation would be favoured by the elimination of the competition previously exerted by rushes, plus the flooding of quadrants after uprooting. These two factors combined would have allowed the expression of a good fraction of the seeds, increasing the correlation (vegetation/seeds stock) with $r^{2}$ value ranging between 0.25 and 0.60 . However, within the cutting and the control plots, the established species did not show any correlation to the seed stock except for perennials. This is probably due to their fast regrowth (perennials abundance did not differ from the reference state) particularly the rushes Juncus maritimus (Lam.) preventing light penetration as light reduction is the principal mechanism through which characteristic species of temporary wetlands are excluded from Juncus maritimus (Lam.) invaded habitats (Tab. 2). Anticipated expectation over the near future is that faster recovery of Juncus maritimus (Lam.) biomass would be accompanied by rapid litter accumulation and the concomitant exclusion of characteristic species diversity [LARKIN et al. 2012].

\section{VEGETATION DYNAMIC}

Inter annual dynamic of vegetation differed between the three treatments, with stronger dynamic in cut and uprooted plots. This reflects changes in vegetation composition, in which hydrology (Axis 1 of the CA) and plant abundance (Axis 2 of the CA) play a major role (Fig. 4). Indeed, these two factors (i.e. biotic and abiotic) together account for $54.16 \%$ of the total variance of vegetation composition in experimental plots. Within the control, the inter annual dynamic was low with high plant abundance due to dominance of Juncus maritimus (Lam.) associated with terrestrials Cynodon dactylon L., Daucus crinitus Desf., Echium plantagineum L., Hordeum maritimum Hudson., Lolium rigidum Gaudin., Medicago polymorpha L. High species abundance by rushes and perennial grasses is often accompanied by a modification of the soils, with an increase in litter and organic matter, which have a strong effect on the dynamic of the vegetation and their recruitment [FACELLI, PICKETT 1991]. Litter accumulation inhibits the characteristic species of temporary wetland that would contribute to a greater dynamic over the two years.

Within the cut plots, the interannual vegetation dynamic was greater compared to control (Fig. 6A, 6B). The centroids moved from characteristic species of temporary wetlands with low-abundance species such as, Spergularia salina J. Presl \& C. Presl., Lythrum junceum Banks \& Solander, Agrostis pourretii Willd., Chara canescens Desv. \& Lois., towards high abundance species with Juncus maritimus (Lam.) across species of the flooded phase Polypogon monspeliensis (L.) Desf., Juncus bufonius L. coexisting with terestrials Daucus crinitus Desf., Anagallis arvensis L., Echium plantagineum L. (Fig. 6A, 6B). The dynamic shows a convergence towards a plant group similar to the control plots group composition, marked by a dominance of rushes. The resumption of the rushes, which was cut only once at the beginning of the experiment, and his significant increase within years in the abundance of perennials (Fig. 6A, 6B), would limit considerably the recruitment of characteristic species of temporary wetlands in the short term.

In the case of the uprooted plots, the interannual vegetation dynamic was much stronger compared to cut plots. This was achieved by an increase in the abundance of species, especially the aquatic characteristics of temporary ponds (Fig 5A, 5B), since the first year with less water demanding species such as Spergularia salina J. Presl \& C. Presl., Juncus bufonius L., Juncus pygmaeus (Rich.) Fourr., Agrostis pourretii Willd., Frankenia laevis L., Isolepsis cernua (Vahl) Roem. \& Schult., and Rumex pulcher L. In the second year, it is mainly the aquatics Nitella opaca Ag., Chara canescens Desv. \& Lois., Ranunculus baudotii Schrank., and Glyceria fluitans (L.) R. Br. With the emergence of the clonal perennial, Bolboschoenus maritimus L., which had invaded some of the plots from the neighbouring area this establishment was probably favoured by: the opening of the gaps after rushes extermination and the longer submersions from the deepening of the plots due to root removal. The appearance of high competitor bulrush Bolboschoenus maritimus L. is likely to have 
similar impact of rushes on herbaceous characteristic communities of these habitats in the short term. Recent study revealed this problem [MENICHINO et al. 2016]; as expected rapid regrowth of the dominant species limits the efficiency of cutting, leading to contrasting expected results. Therefore, relevant well-studied choice of the most advantageous mowing frequency will allow sustained control in rushes belt. Modified traditional land use practices have led to major changes in the vegetation in many types of habitats [HALADA et al. 2011], mainly due to the installation of macrophytes influencing their conservation value. The appropriate management of habitats, along with long-term continuation of moderate land use practices could increase biodiversity [PLIENINGER et al. 2006].

The experiment gave the possibility to test the impact of two techniques (cutting and uprooting) on the restoration of the characteristic species of temporary wetlands. Results show that both techniques allow for the opening of the habitat and the significant increase of species richness and abundance, particularly annuals and characteristic species of temporary wetlands (Fig. 5) from the seed stock, with abundance and richness increasing over two years in relation with the hydrology conditions.

Nevertheless, the uprooting significantly reduced the density and the richness of the seed stock after the root removal and created micro-cavities which remained submerged longer, favouring the installation of other macrophytes Bolboschoenus maritimus apt to have the same effect as the rushes. The cutting technique, followed by the export of the shallow litter, seems to have had less effect on the seed stock, but needs to be regularly maintained with optimum frequency to control the rapid regrowth of the rushes. The technique has also been adopted in many herbaceous restoration trials [BARBARO et al. 2001; BILLETER et al. 2007; DEER 2008; DUTOIT et al. 2001; FYNN et al. 2004; GRYSEELS 1989; LAVERGNE, MOLOFSKY 2006; MENICHINO et al. 2016].

While a resumption of traditional manual cutting activities on the site, together with controlled grazing, is recommended, these activities could guarantee maintenance of the specific characteristic species, which is the main conservation issue for these habitats after the preservation.

\section{CONCLUSIONS}

The initial hypothesis for this study is a reduction of the characteristic species of the temporary wetlands by rushes via competitive exclusion. In order to test the most efficient restoration methods of these species this experiment was carried out. Our results show that both chosen techniques allow the opening of the surrounding belt of the rushes. We recorded a significant increase in the richness and abundance of the species, particularly the restoration success of the characteristic species of the temporary wetland from the seed stock. The cut technique seems to have less effect on the seed stock, but needs to be regularly carried out given the rapid encroachment of the rushes Juncus maritimus (Lam.). Traditional activities held previously by local people, especially the regular cut of rushes in the site is strongly recommended. It could guarantee management of the characteristic species of temporary wetland which constitutes the major stake of conservation in these habitats, along with low cost for managers, adding to these a high implication of local population.

\section{REFERENCES}

AtвIB M. 1979-1980. Etude phytoécologique de la réserve biologique de Mehdia (littoral Atlantique) [Phytoecological study of the Mehdia Biological Reserve (Atlantic coast). Bulletin de l'Institut Scientifique Rabat. [Scientific Institute newsletter Rabat]. Vol. 4 p. 99-188.

Aтвів M. 1983. Etude phytoécologique de la Réserve biologique de Mehdia (littoral atlantique du Maroc). 2. La végétation du milieu dunaire [Phytoecological study of the Mehdia Biological Reserve (Atlantic coast of Morocco). 2. The vegetation of the dune environment]. Bulletin de l'Institut Scientifique Rabat. [Scientific Institute newsletter Rabat] Vol. 4. Iss. 7 supplement.

Barbaro J., Dutoit T., Cozic P. 2001. A six-year experimental restoration of biodiversity by shrub-clearing and grazing in calcareous grasslands of the French Prealps. Biodiversity and Conservation. Vol. 10. Iss. 1 p. 119-135. DOI 10.1023/ A:1016629507196

Beja P., Alcazar R. 2003. Conservation of Mediterranean temporary ponds under agricultural intensification: An evaluation using amphibians. Biological Conservation. Vol. 114. Iss. 3 p. $317-326$. DOI 10.1016/S0006-3207(03)00051$\mathrm{X}$.

Biggs J., Williams P., Whitfield M., Nicolet P., Weatherby A. 2005. 15 years of pond assessment in Britain: Results and lessons learned from the work of pond conservation. Aquatic Conservation: Marine and Freshwater Ecosystems. Vol. 15. Iss. 6 p. 693-714. DOI 10.1002/aqc.745.

BignAL E.M., MCCRACKEN D.I. 1996. Low-intensity farming systems in the conservation of the countryside. Journal of Applied Ecology. Vol. 33. No. 3 p. 413-424. DOI 10.2307/ 2404973.

Billeter R., Peintinger M., Diemer M. 2007. Restoration of montane fen meadows by mowing remains possible after 4-35 years of abandonment. Botanica Helvetica. Vol. 117. Iss. 1 p. 1-13. DOI 10.1007/s00035-007-0743-9.

BISCHOFF A. 2002. Dispersal and establishment of floodplain grassland species as a limiting factor in restoration. Biological Conservation. Vol. 104. Iss. 1 p. 25-33. DOI 10.1016/ S0006-3207(01)00151-3.

Blossfeld S., Gansert D., Thiele B., Kuhn A.J., Lösch R. 2011. The dynamics of oxygen concentration, $\mathrm{pH}$ value, and organic acids in the rhizosphere of Juncus spp. Soil Biology and Biochemistry. Vol. 43. Iss. 6 p. 1186-1197. DOI 10.1016 j.soilbio.2011.02.007.

Bonis A. 1993. Dynamique des communautés et mécanismes de coexistence des populations de macrophytes immergées en marais temporaires [Dynamics of communities and mechanisms of coexistence of submerged macrophyte populations in temporary marshes]. Phd Thesis. Université de Montpellier II pp. 173.

BONIS A., LEPART J. 1994. Vertical structure of seed banks and the impact of depth of burial on recruitment in two temporary marshes. Vegetatio. Vol. 112. Iss. 2 p. 127-139. DOI 10.1007 /BF00044687.

Brezinová T., Vymazal J. 2014. Competition of Phragmites australis and Phalaris arundinacea in constructed wetlands with horizontal subsurface flow - does it affect $\mathrm{BOD}_{5}$, COD and TSS removal? Ecological Engineering. Vol. 73 p. 53-57. DOI 10.1016/j.ecoleng.2014.09.022. 
BROCK M. 1998. Are temporary wetlands resilient? Evidence from seed banks of Australian and Sounth African wetlands. In: Wetlands for the future. Eds. A.J. McComb, J.A. Davis. Contributions from INTECOL's V International Wetlands Conference. Adelaide. Gleneagles Publishing p. 193-206.

Brock M.A., Crosslé K. 2002. Seed-bank and vegetation responses to timing, duration and frequency of flooding in temporary wetlands. International Association of Theoretical and Applied Limnology. Vol. 28. Iss. 4 p. 1756-1761. DOI 10.1080/03680770.2001.11901927.

Council Directive 92/43/EEC of 21 May 1992 on the conservation of natural habitats and of wild fauna and flora.

De Belair G. 2005. Dynamique de la végétation de mares temporaires en Afrique du Nord (Numidie orientale. N.E. Algérie) [Dynamics of temporary pond vegetation in North Africa (Eastern Numidia, N.E. Algeria)]. Ecologia Mediterranea. Vol. 31. Iss. 1 p. 83-100.

DERR J.F. 2008. Common reed (Phragmites australis) response to mowing and herbicide application. Invasive Plant Science and Management. Vol. 1. Iss. 1 p. 12-16. DOI 10.1614/IPSM-07001.1 .

Dutoit T., Gerbaud E., Ourcival J. M., Roux M., Alard D. 2001. Recherche prospective sur la dualité entre caractéristiques morphologiques et capacités de compétition des végétaux: le cas des espèces adventices et du blé [Prospective research on the duality between morphological characteristics and competitive abilities of plants: the case of weed species and wheat]. Comptes Rendus de l'Académie des Sciences, Sciences de la vie. Vol. 324. Iss. 3 p. 261-272. DOI 10.1016/ S0764-4469(00)01296-8.

ERWIN G.N., WeTZEL R.G. 2002. Influence of dominante macrophyte Juncus effusus on wetland plant species richness diversity and community composition. Oecologia. Vol. 130. Iss. 4 p. $626-636$.

ERWIN L.K. 2009. Wetlands and global climate change: the role of wetlands restoration in changing world. Ecology and Management. Vol. 17. Iss. 1 p. 71-84. DOI 10.1007/s11273008-9119-1

Facelli M., Pickett S. 1991. Plant litter: Its dynamics and effects on plant community structure. Botanical Review. Vol. 57. Iss. 1 p. 1-32. DOI 10.1007/BF02858763.

Fennane M., Ibn Tattou M., Mathez J., Ouyahya A., El OuAlidi J. 1999. Flore pratique du Maroc: Pteridophyta, Gymnospermae, Angiospermae (Lauraceae-Neuradaceae) [Practical flora of Morocco: Pteridophyta, Gymnospermae, Angiospermae (Lauraceae-Neuradaceae)]. Vol. 1. Série Botanique 36. Rabat, Morocco. Travaux de l'Institut Scientifique. ISBN 9954-0-1456-X pp. 558.

Fennane M., Ibn Tattou M., Ouyahya A., El Oualidi J. 2007. Flore pratique du Maroc: Angiospermae (Leguminosae Lentibulariaceae) [Practical flora of Morocco: Angiospermae (Leguminosae - Lentibulariaceae)]. Vol. 2. Série Botanique 38. Rabat, Morocco. Travaux de l'Institut Scientifique. ISBN 2366600003 pp. 636.

Fennane M., Ibn Tattou M., El Oualidi J. 2014. Flore pratique du Maroc: Dicotylédones, Monocotylédones [Practical flora of Morocco: Dicotylédones, Monocotylédones]. Travaux de 1'Institut Scientifique. Vol. 3. Série Botanique 40. Rabat. Morocco. Travaux de l'Institut Scientifique. ISBN 2366621000 pp. 794.

FYNN R.W.S., MORRIS C.D., EDWARDS T.J. 2004. Effect of burning and mowing on grass and forb in a long-term grassland experiment. Applied Vegetation Science. Vol. 7. Iss. 1 p. 1-10. DOI 10.1111/j.1654-109X.2004.tb00589.x.

Gómez-Baggethun E., Mingorria S., Reyes-Garcia V., Calvet L., Montes C. 2010. Traditional ecological knowledge trends in the transition to a market economy: Empirical study in the Dõnana Natural Areas. Conservation Biology. Vol. 24. No. 3 p. 721-729. DOI 0.1111/j.1523-1739.2009. 01401.x.

Grillas P., Roche J. 1997. Végétation des marais temporaires : écologie et gestion [Vegetation of temporary ponds]. Conservation des zones humides méditerranéennes. No. 8. Arles. Tour du Valat. ISBN 2910368157 pp. 86.

GRILlaS P., TAN HAM L. 1998. Dynamique intra-et-interannuelle de la végétation dans les mares de la Reserve Naturelle de Roque-Haute: programme d'étude et résultats préliminaires [Intra-and-inter-annual dynamics of vegetation in the pools of the Roque-Haute Natural Reserve: study program and preliminary results]. Ecologia Mediterranea. Vol. 24. Iss. 2 p. $215-222$.

GRYSEELS M. 1989. Nature management experiments in a derelict reedmarsh. I. Effects of summer mowing. Biological Conservation. Vol. 47. Iss. 3 p. 171-193.

Güsewell S., Le Nedic C., Buttler A. 2000. Dynamics of common red (Phragmites australis Trin) in Swiss fens with different management. Wetland Ecology and Management. Vol. 8. Iss. 6 p. 375-389.

Halada L., Evans D., Romao C., Petersen J.E. 2011. Which habitats of European importance depend on agricultural practices? Biodiversity and Conservation. Vol. 20. Iss. 11 p. 2365-2378. DOI 10.1007/s10531-011-9989-z.

Houlahan .J.E., FindLAY C.S. 2004. Effect of invasive plants species on temperate wetland plant diversity. Conservation Biology. Vol. 18. No. 4 p. $1132-1138$. DOI $10.1111 /$ j.15231739.2004.00391.x.

JANSEN A.J.M., RoelofS J.G.A. 1996. Restoration of CirsioMolinietum wet meadows by sod cutting. Ecological Engineering. Vol. 7. Iss. 4 p. 279-298. DOI 10.1016/S09258574 (96)00022-5.

Jones M.B., Kansimme F., SAunders M.J. 2016. The potential use of papyrus (Cyperus papyrus L.) wetlands as a source of biomass energy for Sub-Saharan Africa. Global Change Biology: Bioenergy. Vol. 10. Iss 1 p. 4-11. DOI $10.1111 /$ gcbb. 12392.

Kahmen S., Poschlod P., Schreiber K. 2002. Conservation management of calcareous grasslands. Changes in plant species composition and response of functional traits during 25 years. Biological Conservation. Vol. 104. Iss. 3 p. 319328. DOI 10.1016/S0006-3207(01)00197-5.

KEDDY A.P. 2010. Wetlands ecology: Principles and conservation. New York. Cambrigde University Press. ISBN 9780521739672 pp. 497.

Kent M., CoKer P. 1992. Vegetation description and analysis. A Practical Approach. New York. John Wiley and Sons. ISBN 978-0-471-49092-0 pp. 363.

KerCher S.M., ZeDLER J.B. 2004. Multiple disturbances accelerate invasion of reed canary grass (Phalaris arundinacea L.) in a mesocosm study. Oecologia. Vol. 138. Iss. 3 p. 455-464. DOI 10.1007/s00442-003-1453-7.

Kolos A., Banaszak P. 2013. Mowing as a tool for wet meadows restoration: Effect of long term management on species richness and composition of sedge dominated wetland. Ecological Engineering. Vol. 55 p. 23-28. DOI 10.1016/ j.ecoleng.2013.02.008.

Larkin D.J, Freyman M.J., Lishawa S.C., Geddes P. Tuchman N.C. 2012. Mechanisms of dominance by the invasive hybrid cattail Typha glauca. Biological Invasions. Vol. 14. Iss. 1 p. 65-77. DOI 10.1007/s10530-011-0059-y.

Lavergne S., Molofsky J. 2006. Control strategies for the invasive reed canarygrass (Phalaris arundinacea L.) in North American Wetlands: The need for an integrated management plan. Natural Areas Journal. Vol 26. Iss. 2 p. 208-214. DOI 10.3375/0885-8608(2006)26[208:CSFTIR]2.0.CO;2. 
Lavorel S., Debussche M., Lebreton J.D., LePart J. 1993. Seasonal patterns in the seed bank of Mediterranean oldfields. Oikos. Vol. 67. No. 1 p. 114-128. DOI 10.2307/ 3545102 .

LINDIG-CISNEROS R., ZEDLER J. 2002. Halophyte recruitment in a salt marsh restoration site. Estuaries. Vol. 25. Iss. 6A p. 1174-1183. DOI 10.1007/BF02692214.

Lishawa S.C., Beth A.L., Albert D.A., Tuchman N.C. 2015. Biomass harvest of invasive Typha promotes plant diversity in a Great Lakes coastal wetland. Restoration Ecology. Vol. 23. No. 3 p. $228-237$. DOI $10.1111 /$ rec. 12167.

MacDonald D., Crabtree J.R., Wiesinger D., DaX T., Stamou N., Fleury P., Gutierrez-Lazpita J., Gibton A. 2000. Agricultural abandonment in mountain areas of Europe: Environmental consequences and policy response. Journal of Environnemental Management. Vol. 59. Iss. 1 p. 47-69. DOI 10.1006/jema.1999.0335.

MAIRE R. 1952-1987. Flore de l'Afrique du Nord. Lechevalier [Flora of Africa]. Paris, France. Lechevalier.

Medail F., Michaud H., Molina J., Paradis G., Loisel R. 1998. Conservation de la flore et de la végétation des mares temporaires dulçaquicoles et oligotrophes de France méditerranéenne [Conservation of the flora and vegetation of the temporary freshwater and oligotrophic pools of Mediterranean France]. Ecologia Mediterranea. Vol. 24. Iss. 2 p. $119-134$.

Menichino N.M., Fenner N., Pullin A.S., Jones P.S., Guest J., JONES L. 2016. Contrasting response to mowing in two abandoned rich fen plant communities. Ecological Engineering. Vol. 86 p. 210-222. DOI 10.1016/j.ecoleng.2015.09.073.

MiLleR J.R, HobBS R.J. 2007. Habitat restoration - do we know what we're doing? Restoration Ecology. Vol. 15. Iss. 3 p. 382-390. DOI 10.1111/j.1526-100X.2007.00234.x.

MiLlER T.W. 2016. Integrated strategies for management of perennial weeds. Invasive Plant Science and Management. Vol. 9. Iss. 2 p. 148-158. DOI 10.1614/IPSM-D-15-00037.1.

MioduszewSKi W., OKRUSZKO T. 2012. Protection of natural wetlands - the examples of conflicts. Journal of Water and Land Development. No. 16 (I-VI) p. 35-42.

Natura code 3170, 92/43/CCE (European Community Directive 92/43/EEC on the Conservation of Natural Habitats and of Wild Fauna and Flora. the Habitats Directive) http://jncc.defra.gov.uk/pdf/HDir_Rpt.pdf.

O'ROURKE E. 2006. Changes in agriculture and the environment in an upland region of the Massif Central, France. Environmental Science and Policy. Vol. 9. Iss. 4 p. 321-332. DOI 10.1016/j.envsci.2006.01.008.
Oertli B., Indermuehle N., Angelibert S., Hinden H., Stoll A. 2008. Macroinvertebrate assemblages in 25 high alpine ponds of the Swiss National Park (Cirque of Macun) and relation to environmental variables. Hydrobiologia. Vol. 597. Iss. 1 p. 29-41. DOI 10.1007/s10750-007-9218-7.

Plieninger T., Hochtl F., SpeK T. 2006. Traditional land-use and nature conservation in European rural landscapes. Environmental Science and Policy. Vol. 9. Iss. 4 p. 317-321. DOI 10.1016/j.envsci.2006.03.001.

Ramdani M., Flower R.J., ElKhiati N., Kraïem M.M., FAthi A.A., Birks H.H., PATRICK S.T. 2001. North African wetland lakes: Characterization of nine sites included in the CASSARINA Project. Aquatic Ecology. Vol. 35. Iss. 3-4 p. 281-302. DOI 10.1023/A:1011957324901.

SAHIB N. 2018. How species colonize gaps after soil disturbance in temporary ponds? Implication of species traits. Journal of Water and Land Development. No. 38 p. 137-145. DOI 10.2478/jwld-2018-0050.

SnOdgrass J.W., KOMOROSKI M.J., Bryan L.A. Jr., BURGER J. 2000. Relationships among isolated wetland size, hydroperiod, and amphibian species richness: implications for wetland regulations. Conservation Biology. Vol. 14. Iss. 2 p. 414-419. DOI 10.1046/j.1523-1739.2000.99161.x.

UNGAR I.A. 2001. Seed banks and seed population dynamics of halophytes. Wetlands Ecology and Management. Vol. 9. Iss. 6 p. 499-510. DOI 10.1023/A:1012236829474.

WAHLMAN H., Milberg P. 2002. Management of semi-natural grassland vegetation: evaluation of a long-term experiment in southern Sweden. Annals Botanici Fennici. Vol. 39. Iss. 2 p. $159-166$.

Wetzel P., Van Der Valk A., Toth L. 2001. Restoration of wetland vegetation on the Kissimmee River floodplain: potential role of seed banks. Wetlands. Vol. 21. Iss. 2 p. 189 198.

Williams P., Whitfield M., Biggs J., Bray S., Fox G., NicoLET P., SEAR D. 2004. Comparative biodiversity of rivers, streams, ditches and ponds in an agricultural landscape in Southern England. Biological Conservation. Vol. 115. Iss. 2 p. 329-341. DOI 10.1016/S0006-3207(03)00153-8.

Zaidi M., BAghDad B., ChakiRI S. TALeb A. 2016. Characterization of the biodegradation of Kasbahs of the Gharb Region (Mehdia and Kenitra Kasbahs, Morocco). Open Journal of Ecology. Vol. 6 p. 753-766. DOI 10.4236/ oje.2016.613067.

ZEDLER J.B. 2000. Progress in wetland restoration ecology. Trends in Ecology and Evolution. Vol. 15. Iss. 10 p. 402 407. DOI 10.1016/S0169-5347(00)01959-5.

\section{Nargis SAHIB}

\section{Wpływ dwóch technik gospodarowania stosowanych do ograniczenia obfitości Juncus maritimus (Lam.) w wybranych okresowych środowiskach podmokłych}

\section{STRESZCZENIE}

Umiarkowane zarządzanie okresowymi środowiskami podmokłymi jest jedną z najbardziej właściwych metod ich odtwarzania i ochrony. Zaniechanie użytkowania może prowadzić do znaczącej dominacji biomasy makrofitów, takich jak Juncus maritimus, która zmienia strukturę zespołu roślinnego, ogranicza różnorodność gatunkową i stanowi zagrożenie dla ochrony siedlisk. Eksperyment prowadzono w przybrzeżnym rezerwacie Sidi Boughaba w Maroku. Testowano dwie techniki gospodarowania - cięcie i wykorzenianie sitowia. Założono cztery poletka doświadczalne $(4.2 \times 2.9 \mathrm{~m}) \mathrm{w}$ pasie sitowia, stosując poletka bez jakichkolwiek zabiegów jako kontrolę. Strukturę roślinności i poziom wody monitorowano 
sześciokrotnie na 96 kwadratach w ciągu dwóch lat, trzykrotnie w ciągu roku (w lutym, kwietniu i czerwcu). Badano obfiobfitość i bogactwo gatunkowe oraz zagęszczenie banku nasion w każdym poletku. Wyniki dowodzą, że obie techniki umożliwiają otwarcie siedlisk ze znaczącym wzrostem bogactwa i obfitości gatunków, szczególnie przywracanie z banku nasion gatunków charakterystycznych dla siedlisk podmokłych. Technika wycinania skutkuje, jak się wydaje, słabszym wpływem na bank nasion, stosowana regularnie ułatwia gwałtowny rozrost sitowia.

Słowa kluczowe: bank nasion, Juncus maritimus (Lam.), ochrona okresowych środowisk podmoktych, podejście doświadczalne, sitowie, techniki zarządzania 